\title{
First report of Erysiphe convolvuli on Convolvulus arvensis and Calystegia sepium in Chile with a description of the sexual state
}

\section{Primera determinación de Erysiphe convolvuli sobre Convolvulus arvensis y Calystegia sepium en Chile con una descripción del estado sexual}

\author{
José luis Henríquez S.*, Paula Alarcón C. \& Pablo Sandoval L. \\ Departamento de Sanidad Vegetal, Facultad de Ciencias Agronómicas, Universidad de Chile. Casilla 1004, Santiago, Chile. \\ *jhenriqu@uchile.cl
}

\begin{abstract}
RESUMEN
La correhuela (Convolvulus arvensis L.) es una planta cosmopolita, ampliamente distribuida en Chile y considerada como una maleza de importancia en cultivos agrícolas. Por muchos años se ha observado la presencia de un oídio creciendo profusamente sobre sus hojas y tallos pero, recientemente, en el otoño de 2010 se observó por primera vez el teleomorfo de este hongo. Se realizó una prospección de plantas sintomáticas encontrándose la forma sexual del oídio desde la Región de Coquimbo hasta la Región del Libertador Bernardo O’Higgins. El patógeno fue identificado como Erysiphe convolvuli var. convolvuli, el cual no había sido reportado anteriormente en el país. Muestreos realizados en el otoño de 2012 permitieron determinar, además, la presencia de Erysiphe convolvuli var. calystegiae en dos muestras de Calystegia sepium, observándose casmotecios inmaduros en una de ellas.
\end{abstract}

Field bindweed (Convolvulus arvensis L.) known in Chile as "correhuela" is a common weed spread throughout the north central region of the country from Tarapaca to Llanquihue and in the Juan Fernandez islands (Matthei 1995). The weed is frequent on agricultural fields, being a problem for annual and perennial crops due to its perennial character and climbing habit, allowing it to grow on top of the crops. It is also problematic in urban areas where it is an important weed in parks and home gardens. Field bindweed is usually controlled through mechanical means and herbicides, but its presence in the fields is recurrent due to its ability to growth back from root pieces and rhizomes coming from endogenous buds in the roots, which can be found deep in the soil profile (Kogan 1992). Calystegia sepium (L) R.Br., the hedge bindweed, known locally as "carrizalillo" or "suspiro" is found in Chile in the Metropolitan Region, from Bio-Bio to Llanquihue, and in Eastern island (Matthei 1995). It is considered a minor weed found in wet areas, alongside roads, and climbing on fences. $C$. arvensis and $C$. sepium are two cosmopolitan weeds in the Convolvulaceae family, while Ipomoea batatas (L.) Lam. is a cultivated crop.

On a worldwide basis, two powdery mildew species are reported on field bindweed, Erysiphe convolvuli DC. (Braun 1995) and Leveillula taurica (Lév.) Arnaud (Glawe et al. 2003). Three varieties of E. convolvuli are described, regarding the number of ascospores per ascus and the associated host. E. convolvuli var. convolvuli is found associated with Convolvulus and has 3 to 4 ascospores per ascus, while E. convolvuli var. calystegiae U. Braun is found on Calystegia and has 5 to 6 ascospores per ascus. E. convolvuli var. dichotoma R.Y.Zheng \& G.Q.Chen is distinct from both by having ramified appendages on its chasmothecia (Braun 1995). Powdery mildew has been frequently observed on field bindweed along its distribution area in Chile as a white ectotrophic mycelium for at least 15 years by the authors. Interestingly, during fall 2010 chasmothecia were found for the first time, across a wide area of central Chile. Two specimens, labeled as $E$. convolvuli, are held by the phytopathological herbarium of the Universidad Austral de Chile; nevertheless, the species has never been officially reported and is not included in the most complete checklist of fungal phytoparasites in Chile (Mujica \& Vergara 1980). The fungus has been also recently described for North America (Glawe et al. 2003) and Turkey (Sert et al. 2006).

A collection of infected field bindweed was made during fall 2010, after the first detection of chasmothecia on bindweed samples found in Calle Larga, Los Andes, Chile. Powdery mildew infected hedge bindweed were also found during the fall 2012. Samples were stained with phloxin and microscopic examination was performed under a phase 
contrast microscope (Axiostar Plus, Carl Zeiss, Germany). Morphometric characteristics were compared with those described in literature (Braun 1995, Glawe et al. 2003).

Chasmothecia on field bindweed were spherical, thick walled, yellowish to reddish when immature turning dark brown in mature specimens (Fig. 1), 110-150 $\mu \mathrm{m}$ in diameter, with scarce unbranched micellioid hyaline appendages, 5$7 \times 66-195 \mu \mathrm{m}$ (Fig. 2A); asci 3 to 4 per chasmothecium, subglobose, 4-spored, 46 × $80 \mu \mathrm{m}$; ascospores elliptic, hyaline 22.5-28 x 12.5-17.5 $\mu \mathrm{m}$ (Fig. 2B). These characteristics allow us to determine this powdery mildew as Erysiphe convolvuli var. convolvuli. A representative specimen was deposited in the Herbaria of the Natural History Museum Santiago, Chile (SGO). Chasmothecia on hedge bindweed were immature, spherical, thick walled, yellowish to reddish turning dark brown, 102-129 $\mu \mathrm{m}$ in diameter; micellioid hyaline appendages 6-6.5 x 80-112 $\mu \mathrm{m}$; asci 3 to 4 per chasmothecium, subglobose, $35.4 \times 56.3$ $\mu \mathrm{m}$. The specimens were determined as E. convolvuli var. calystegiae based on its host.

Material examined: Convolvulus arvensis; Metropolitan Region, Santiago, La Pintana (3334'13.44'S; 70³8'03”W), 21-IV-2010, leg. and det. J. L. Henriquez (SGO 160482). Region of Libertador Bernardo O'Higgins, Codegua, (34 24'07.25”S; 70 53'11.39”W), 29-IV-2010, leg. and det. J. L. Henriquez (SGO 160483). Calystegia sepium;
Chile, Metropolitan Region, Alto Jahuel (334' $15.25^{\prime \prime S}$; 7040'15'W), 27-IV-2012, leg. and det. J. L. Henriquez (SGO 161332).

E. convolvuli var. convolvuli and E. convolvuli var. calystegiae have not been described in Chile before, besides some specimens which are labeled as E. convolvuli in the Herbario Fitopatológico of Universidad Austral de Chile from samples taken from San Carlos and Chillan in the Bio-Bio Region, but the presence of chasmothecia in those samples is unknown. Interestingly, the teleomorph of the grape powdery mildew (Erysiphe necator Schwein) was described as well for the first time in Chile a few years ago (Silva 2005). These new findings could be indicating a shift in environmental factors that prompted the development of the sexual stage of powdery mildew fungi in the central region of Chile. However, it is not clear how environmental changes could influence chasmothecial development. Only dryness has been observed to influence its development (Braun 1995), dryer weather at the end of the summer could explain this situation. The introduction of a previously missing mating type could also explain this phenomenon, but there is a lack of information on this respect. On the other hand, most plant pathologists work mainly with pathogens on cultivated plants, overlooking pathogens on weeds and wild plants, which can explain why this common powdery mildew has not been reported previously.

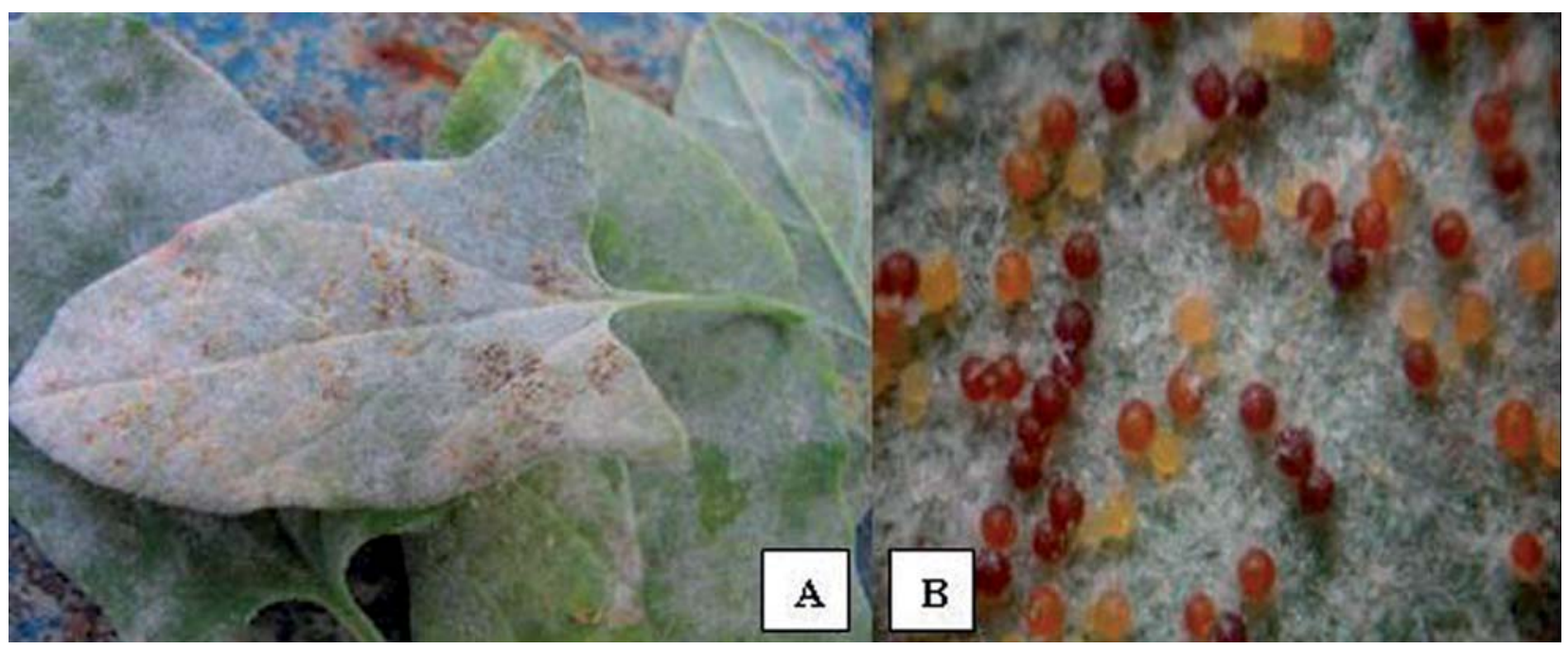

Figure 1. A. Mycelia and chasmothecia of Erysiphe convolvuli var. convolvuli on leaves of Convolvulus arvensis L. B. Immature chasmothecia.

Figura 1. A. Micelio y casmotecios de Erysiphe convolvuli var. convolvuli en hoja de Convolvulus arvensis L. B. Casmotecios inmaduros. 


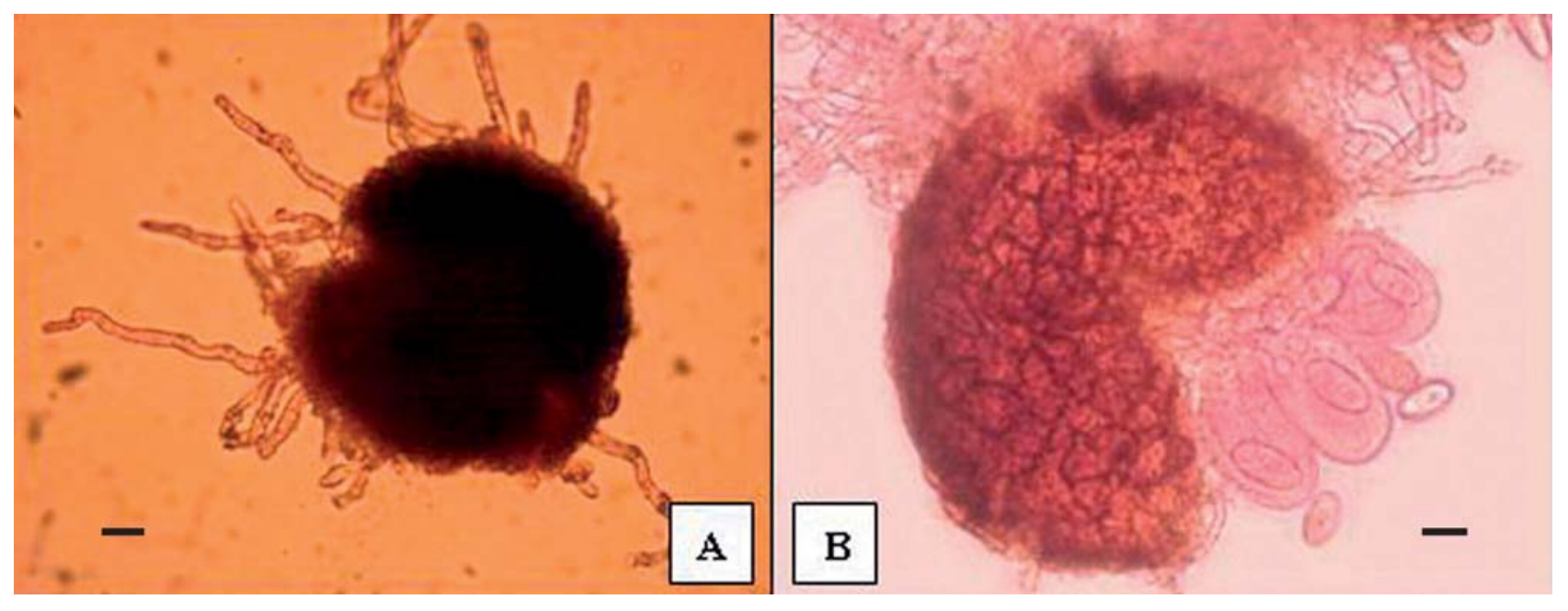

FIGURE 2. Chasmothecium of Erysiphe convolvuli var. convolvuli showing, A. unbranched appendages $($ Bar $=20 \mu \mathrm{m})$; B. asci with ascospores $(\mathrm{Bar}=10 \mu \mathrm{m})$.

FIgURA 2. Casmotecio de Erysiphe convolvuli var. convolvuli mostrando, A. apéndices no ramificados (Barra $=20 \mu \mathrm{m})$; B. ascos con ascosporas $(\mathrm{Bar}=10 \mu \mathrm{m})$.

\section{LITERATURE CITED}

Braun, U. 1995. The Powdery Mildews of Europe. Gustav Fischer Verlag, Jena. 226 pp.

Glawe, D.A., G.E. Windom, G.G. Grove \& J.S. Falacy. 2003. First report of powdery mildew of Convolvulus arvensis (field bindweed) caused by Erysiphe convolvuli var. convolvuli in North America. Online. Plant Health Progress doi:10.1094/PHP-2003-1021-01-HN. http:// www.plantmanagementnetwork.org/pub/php/brief/2003/ bindweed/ Viewed. May $15^{\text {th }}, 2010$.

Kogan, M. 1992. Malezas, ecofisiología y estrategias de control.
Facultad de Agronomía, Pontificia Universidad Católica de Chile. 382 pp.

Matthei, O. 1995. Manual de las malezas que crecen en Chile. Alfabeta Impresos, Santiago, Chile. 545 pp.

Mujica, F. \& C. Vergara. 1980. Flora fungosa chilena. Facultad de Agronomía, Universidad de Chile. 308 pp.

Sert, H., H. Sümbül \& K. Sterflinger. 2006. Occurrence of powdery mildews on new hosts in Turkey. Phytoparasitica 34(5): 474-476.

SiLVA, R. 2005. Identificación de la fase sexual del oídio de la vid (Uncinula necator Burr.) en la zona central de Chile. Aconex (Chile) 87: 13-17.

Recibido: 07.03.12

Aceptado: 24.07.12 